DOI https://doi.org/10.18551/rjoas.2017-10.35

\title{
HOUSEHOLD ECONOMIC MODEL TO IMPROVE SMALL-SCALE FISHERMAN INCOME AT RURAL MINAPADI (RICE-FISH SYSTEM) DEVELOPMENT PROGRAM IN DONGGALA, CENTRAL SULAWESI
}

\author{
Mardjudo Ahsan* \\ Faculty of Fisheries, University of Alkhairaat, Palu, Indonesia \\ Yasin Muhammad \\ Faculty of Economic, University of Alkhairaat, Palu, Indonesia \\ *E-mail: ahsan.mardjudo@gmail.com
}

\begin{abstract}
The general purpose of the study is to find information about and analyze model of Rural Minapadi (Rice-Fish System) Development Program to improve household income of smallscale fishermen. The specific purpose of the study is to develop economic model and household economic behavior of small-scale fisherman through Rural Minapadi (Rice-Fish System) Development Program in Donggala, Central Sulawesi. The population is small-scale fishermen in Donggala who participate in Rural Minapadi (Rice-Fish System) Development Program. Multi-stage sampling is the sampling method. Model of household economy for small-scale fishermen is developed from 17 (seventeen) equations or endogenous variables that consists of 8 (eight) behavioral equations and 9 (nine) identity equations. Two Stage Least Squares (2SLS) and simulation analysis are used to give estimation towards parameters in simultaneous equation. Data analysis uses Statistical Analysis System (SAS). The findings show that household economic model of small-scale fisherman can be described based on the amount of marine commodity they are able to catch, the amount of work they do, household food and non-food spending that tends to increase when there is an increase in size of fishing boat, gasoline consumption and fishing frequency. Based on the analysis, the household economic model for small-scale fisherman is valid theoretically and it can provide accurate description. In order to get larger amount of marine commodity that eventually results in an increase of income and welfare, some household decisions are taken and some policy is established; they are increase in fishing frequency and workload as well as some allowance from the government in the form of fishing equipments and subsidy for gasoline.
\end{abstract}

\section{KEY WORDS}

Small-scale fisherman, household, economic model, fishing.

Fishing industry in Donggala, Central Sulawesi is dominated by conventional, smallscale fishermen and as the result level of productivity remains low. In order to improve fishermen's productivity, sufficient fishing equipment becomes the requirement so that marine commodity the fishermen catch can be sold in both local and regional market. Currently, small-scale fishermen have yet been able to increase their productivity and as the result, they have pretty low income.

In order to improve small-scale fisherman productivity and achieve the 2010-2014 Mission of the Ministry of Marine and Fishery, the government established Rural Minapadi (Rice-Fish System) Development Program. It is the continuation of the government allowance (Bantuan Langsung Masyarakat) during the 2009-2010 Independent Marine and Fishery PNPM. One of the goals of Rural Minapadi (Rice-Fish System) Development Program is to increase productivity and income of small-scale fisherman through business groups or Kelompok Usaha Bersama. Kelompok Usaha Bersama is a group of which member is fisherman; its foundation is concensus to increase member's income. 
The business group is media to achieve the goal of Rural Minapadi (Rice-Fish System) Development Program. Establishemnt of business groups in village or regions is a breakthrough so that fisherman can achieve economic welfare. Business group has been established in Donggala since 2011. Attention should be paid to the fishermen in Donggala because they rely upon their fishing job. Due to lack of capital, the fishermen still use conventional fishing equipment and conventional fishing boats.

Establishment and development of fishing industry that was and has been going on currently focuses on increasing productivity of small-scale fishermen. Meanwhile, underlying obstacles in the establishment and development of the fishing industry are incompetent human resources, lacking access to capital and facilities, technology and market as well as socio-cultural factor; all of them result in the fishermen having low income. Careful analysis should be conducted to overcome the obstacles and improve the fishermen's welfare.

The government has taken some efforts to solve the issues for example (1) some policy to improve skills of the fishermen in the form of training of which purpose is to enable the fishermen getting higher amount of marine commodity; (2) some policy of which purpose is to facilitate the fishermen getting some capital through PEMP program which began in 2000 and was going on until 2010; (3) some policy that allows the fishermen getting motorized fishing boats; and (4) some policy related to the socio-cultural issue where the government works with religious institutions of which orientation is the local wisdom of Donggala, Central Sulawesi.

The government policy about fishing industry has been established and implemented all over Indonesia. However, the implementation has yet been optimum because the fishermen, more particularly small-scale fishermen, are still living in poverty. Therefore, studies of which purpose is to develop skills of human resources in order that they are able to achieve financial independence, without relying on the government allowance should be conducted.

Studies about small-scale fishing industry have been conducted previously; however there has yet been study focusing on household economic model for small-scale fishermen who use conventional rowing boat or lower than 12-PK motorized fishing boat and conventional equipment for fishing. Analysis in the study focuses on developing household economic model for small-scale fishermen emphasizing on fishing activities, workload, income and household spending of small-scale fishermen.

The general purpose of the study is to find information about and analyze model of Rural Minapadi (Rice-Fish System) Development Program to improve household income of small-scale fishermen. The specific purpose of the study is to develop economic model and household economic behavior of small-scale fisherman through Rural Minapadi (Rice-Fish System) Development Program in Donggala, Central Sulawesi. The population is small-scale fishermen in Donggala who participate in Rural Minapadi (Rice-Fish System) Development Program.

\section{METHODS OF RESEARCH}

Setting and Scope of the Study. The setting of the study is Makassar Street in Donggala, Central Sulawesi. The study is a survey that is a study of which aim is to give factual description of a current phenomenon and also describes correlation between phenomena, test hypotheses as well as making interpretation and obtain meaning from the phenomenon being analyzed (Nazir M, 2003). Survey refers to taking samples from population using questionnaire as instrument to get primary data from respondents. The scope of the study is to describe and analyze household economic model of small-scale fishermen who participate in Rural Minapadi (Rice-Fish System) Development Program. Analyzing household economic model of small-scale fishermen involves the analysis of production, workload, income and spending. The variables are analyzed using simultaneous equation that in general is dynamic and specific for household economic model. Two Stage Least Squares (2SLS) gives estimation towards parametersof the model while data analysis uses Statistical Analysis System (SAS). 
Identification and Estimation of Model. Purpose of model identification is to find out whether estimation of parameter for structural equation can be conducted. When there is bias, the equation can be identified, but when it is not biased, the equation cannot be identified. Process of identification in the study use order condition as the requirement as follow: when $(\mathrm{G}-\mathrm{g})+(\mathrm{K}-\mathrm{k})>\mathrm{G}-1$ the equation isconsidered overidentified (over), where $G=$ number of endogenous variable in the model, $g=$ number of endogenous variable in the equation, $\mathrm{K}=$ number of exogenous variable in the model, $\mathrm{k}=$ number of exogenous variable in the equation.

\section{RESULTS AND DISCUSSION}

Validation. Purpose of validation is to find out how accurate endogenous variable is to predict the household economic model of small-scale fishermen in in Rural Minapadi (RiceFish System) Development Program. The result reveals that the model is able to describe accurate information, the actual information (score) is pretty similar to the predictive information (score).

The statistical analysis of predictive ability of the model presented in Table 1 shows that the endogenous variables in the household economic model of small-scale fishermen in in Rural Minapadi (Rice-Fish System) Development Program conveys predictive means that is similar to the actual mean; it means the model has good predictive ability. $U^{\mathrm{M}}$ score that is close to zero means the model does not have systematic bias. In addition, $U^{S}$ that is also close to zero means the analysis of the simulation can follow the increase or decrease of the actual data. $U^{C}$ that generally is close to one means error is not significant and able to follow certain pattern but spread out to all observations.

Table 1 - Predictive Ability Level of the Model

\begin{tabular}{llllll}
\hline Variable & Actual Mean & Predictive Mean & $\left(\mathrm{U}^{\mathrm{M}}\right)$ & $\left(\mathrm{U}^{\mathrm{S}}\right)$ & $\left(\mathrm{U}^{\mathrm{C}}\right)$ \\
\hline Production (kg) & 208.60 & 208.60 & 0.00 & 0.02 & 0.98 \\
Husband's non-fishing workload (HOK) & 17.90 & 17.74 & 0.02 & 0.01 & 0.98 \\
Wife's non-fishing workload (HOK) & 3.27 & 3.37 & 0.00 & 0.06 & 0.94 \\
Income from fishing activities (Rp) & $2,584,835.00$ & $2,584,840.00$ & 0.00 & 0.03 & 0.97 \\
Reception from fishing activities (Rp) & $5,213,918.00$ & $5,213,922.00$ & 0.00 & 0.02 & 0.98 \\
Non-fixed fee / variabel fee(Rp) & $2,629,082.00$ & $2,629,082.00$ &. &. &. \\
Income from non-fishing activities (Rp) & $1,627,938.00$ & $1,618,917.00$ & 0.00 & 0.01 & 0.99 \\
Household income (Rp) & $4,212,773.00$ & $4,203,756.00$ & 0.00 & 0.07 & 0.93 \\
Food consumption (Rp) & $2,452,062.00$ & $2,446,322.00$ & 0.00 & 0.16 & 0.84 \\
Non-food consumption (Rp) & $1,562,887.00$ & $1,560,055.00$ & 0.00 & 0.33 & 0.67 \\
Household consumption (Rp) & $4,014,948.00$ & $4,006,378.00$ & 0.00 & 0.12 & 0.88 \\
\hline
\end{tabular}

Source: SAS Analysis (2015).

$U^{M}$ score is biased proportion that becomes indicator of systematic error. $U^{S}$ score is component of bias variance while $U^{C}$ score is bias covariance. A model has good predictive ability when $U^{M}$ and $U^{C}$ score is close to zero and $U^{C}$ score is close to one. Based on Pindyck and Rubinfeld (1991), a model has good predictive ability when $U^{\mathrm{M}}$ and $U^{\mathrm{C}}$ score is close to zero and $U^{C}$ score is close to one. Based on the validation, the household economic model for small-scale fishermen in Rural Minapadi (Rice-Fish System) Development Program is considered as valid.

Small-Scale Fishermen's Household Economic Model and Behavior. Fishermen's household economic model is basically different from household economic model for agriculture. The difference lies in possesion of property. Household economic for agriculture relies heavily on possession of cultivation area known as private property, while fishermen's household depends on possession of fishing equipment and public resources or known as commen property.

Household model for fisherman is adopted from empirical model of agriculture household. Becker (1965) developed thoery of household through implementation of maximum satisfaction from good consumption into new household economics. There are 2 
(two) processes in household behavior. The first is household production described in production function. The second is household consumption that refers to preference or selection towards consumption of goods; the analysis emphasizes on household time allotment that is categorized as productive time for work and leisure time.

Development of economic household model generally adopts Bagi and Singh (1974)'s theory of household economy. Decision-making in the model is divided into 6 (six) groups namely production, consumption, marketed surplus, human resource/ employment, investment and finance. Studies on economic household of fishermen have been conducted previously for example one conducted by Aryani (1994), Reniati (1998), Muhammad (2002), dan Sutoyo (2005). The models developed in the previous studies have involved some variables relevant to economic condition of fishermen's household in the beaches such as relationship between economic behavior in production, workload, income and spending.

The model of household economy for small-scale fishermen in the study is developed from 17 (seventeen) equations or endogenous variables that consists of 8 (eight) behavioral equations and 9 (nine) identity equations. Two Stage Least Squares (2SLS) is used to give estimation towards parameters in simultaneous equation. Data analysis uses Statistical Analysis System (SAS). Economic behavior of small-scale fishermen's household is elaborated as follows.

Equation for Production. Production of small-scale fishermen depends on fishing experience, fishing activities, husband's fishing workload, numbers of fishing equipment, size of fishing boats/ cold box and gasoline. The equation is as follow:

$$
H T=a o+a 1 P M+a 2 F M+a 3 C T K s m p+a 4 J A T+a 5 U p r h+a 6 B S N+U 1
$$

The result of multiple regression analysis (Anova) conducted simultaneously using SAS version 9.1 is described in Table 2.

Table 2 - Anova of Factors Affecting Production of Small-Scale Fishermen

\begin{tabular}{llllll}
\hline Variance & $\mathrm{db}$ & Total Square & Median & F-ratio & $\operatorname{Pr}>\mathrm{F}$ \\
\hline Regression & 6 & $403,530.00$ & $67,255.01$ & 201.31 & $<.0001$ \\
Residual & 90 & $30,067.90$ & 334.09 & & \\
Total & 96 & $433,597.90$ & & & \\
\hline
\end{tabular}

Source: SAS Analysis, 2015.

Table 2 shows $F_{\text {ratio }}=201.31$ with probability $0.0001<0.01(\alpha=1 \%)$ reject the null hypothesis; it means the independent variables fishing experience, fishing experience, husband's fishing workload, numbers of fishing equipment, size of fishing boats/ cold box and gasoline simultaneously influence production. T-test is used to find out the influence of independent variables towards dependent variable; the analysis is presented in Table 3.

Table 3 - Estimation of Production

\begin{tabular}{llllll}
\hline Variable & Coefficient & Standard Error & t- ratio & $\mathrm{Pr}>|\mathrm{t}|$ & Elastic Coefficient \\
\hline Intercept & -18.25 & 13.53 & & & \\
PM & 1.57 & 0.63 & 2.48 & 0.015 & 0.08 \\
FM & 5.13 & 0.98 & 5.23 & $<.0001$ & 0.38 \\
CTKsmp & 4.95 & 1.78 & 2.77 & 0.0068 & 0.24 \\
JAT & 14.77 & 5.87 & 2.52 & 0.0136 & 0.03 \\
Uprh & 13.57 & 4.46 & 3.04 & 0.0031 & 0.12 \\
BSN & 0.14 & 0.05 & 2.62 & 0.0102 & 0.23 \\
\hline
\end{tabular}

Determinant coefficient $\left(R^{2}\right)$ equals to 0.9260

Source: SAS Analysis, 2015.

Determinant coefficient $\left(R^{2}\right)$ equals to 0.9260 shows the following variables namely fishing experience, fishing experience, husband's fishing workload, numbers of fishing equipment, size of fishing boats/ cold box and gasoline have $92.60 \%$ influence towards production while the remaining $7.40 \%$ is affected by other factors. 
Fishing experience has significant and positive influence towards production where $\mathrm{t}_{\text {ratio }}=2.48$ with probability $0.015<0.05(\alpha 5 \%)$ in two-way testing. Elasticity of 0.08 means each $1 \%$ increase in fishing experience increases production as much as $0.08 \%$ with the assumption that other factors are constant.

Equation for Husband's Non-Fishing Workload. The amount of husband's non-fishing workload is influenced by income from fishing activity and fee from non-fishing activity. The equation is as follow:

$$
C T K s m n p=b o+b 1 P D p+b 2 U T K s m n p+U 2
$$

The result of multiple regression analysis (Anova) conducted simultaneously using SAS version 9.1 is described in Table 4.

Table 4 - Anova of Factors Affecting Husband's Non-Fishing Workload

\begin{tabular}{|l|l|l|l|l|l|}
\hline Variance & $\mathrm{db}$ & Total Square & Median & F-ratio & $\operatorname{Pr}>\mathrm{F}$ \\
\hline Regression & 2 & $1,164.857$ & 582.4285 & 233.97 & $<.0001$ \\
\hline Residual & 94 & 234.002 & 2.489383 & & \\
\hline Total & 96 & $1,398.859$ & & & \\
\hline
\end{tabular}

Table 4 shows $F_{\text {ratio }}=233.97$ with probability $0.0001<0.01(\alpha=1 \%)$ reject the null hypothesis; it means the independent variables income from fishing activities and some money the husbands earn from non-fishing activities simultaneously influence husband's non-fishing workload. T-test is used to find out the influence of independent variables towards dependent variable; the analysis is presented in Table 5.

Table 5 - Estimation of Husband's Non-Fishing Activity (CTKsmnp)

\begin{tabular}{llllll}
\hline Variable & Coefficient & Standard Error & $\mathrm{t}-$ ratio & $\mathrm{Pr}>|\mathrm{t}|$ & Elastic Coefficient \\
\hline Intercept & 20.70518 & 1.195798 & 17.31 & $<.0001$ & \\
PDp & $-2.55 \mathrm{E}-06$ & $1.41 \mathrm{E}-07$ & -18.15 & $<.0001$ & -0.368 \\
UTKsmnp & 0.000045 & 0.000012 & 3.81 & 0.0003 & 0.210 \\
\hline
\end{tabular}

Determinant coefficient $\left(R^{2}\right)$ equals to 0.8292

Determinant coefficient $\left(R^{2}\right)$ equals to 0.8292 shows income from fishing activity and husband's fee from non-fishing activity have $82.92 \%$ influence towards husband's non-fishing workload and the remaining $17.18 \%$ is affected by other factors.

Husband's fee from non-fishing activity has positive and significant influence towards husband's non-fishing workload where $t_{\text {ratio }}=3.81$ with probability $0.003<0.05(\alpha 5 \%)$ in two-way testing. 0.21 elasticity means every $1 \%$ increase in husband's income from nonfishing activity will increase fishermen's household income as much as $0.21 \%$ with the assumption that other factors are constant.

Equation for Wife's Non-Fishing Workload. The amount of wife's non-fishing workload is influenced by income from fishing activity and fee from non-fishing activity. The equation is as follows:

$$
\text { CTKisnp }=c o+c 1 P D p+c 2 U T K i s n p+U 3
$$

The result of multiple regression analysis (Anova) conducted simultaneously using SAS version 9.1 is described in Table 6.

Table 6 - Anova of Factors Affecting Wife's Non-Fishing Workload

\begin{tabular}{|l|l|l|l|l|l|}
\hline Variance & $\mathrm{db}$ & Total Square & Median & F-ratio & Pr $>$ F \\
\hline Regression & 2 & 2977.136 & 1488.568 & 216.83 & $<.0001$ \\
\hline Residual & 94 & 645.3288 & 6.8652 & & \\
\hline Total & 96 & 3622.4648 & & & \\
\hline
\end{tabular}


Table 6 shows $F_{\text {ratio }}=216.83$ with probability $0.0001<0.01(\alpha=1 \%)$ rejects the null hypothesis. It means the independent variables (income from fishing activity and wife's fee from non-fishing activity) simultaneously affect the amount of wife's non-fishing workload. Ttest is used to find out the influence of independent variables towards dependent variable; the analysis is presented in Table 7.

Table 7 - Estimation of Wife's Non-Fishing Activity(CTKisnp)

\begin{tabular}{llllll}
\hline Variabel & Coefficient & Standard Error & t- ratio & $\mathrm{Pr}>|\mathrm{t}|$ & Elastic Coefficient \\
\hline Intercept & 2.049964 & 0.745537 & 2.75 & 0.0072 & \\
PDp & $-5.38 \mathrm{E}-07$ & $2.39 \mathrm{E}-07$ & -2.25 & 0.0269 & -0.426 \\
UTKisnp & 0.000352 & 0.00002 & 17.63 & $<.0001$ & 0.763
\end{tabular}

Determinant Coefficient $\left(R^{2}\right)$ equals to 0.8181

Determinant coefficient $\left(R^{2}\right)$ equals to 0.8181 shows income from fishing activity and wife's fee from non-fishing activity have $81.81 \%$ influence towards wife's non-fishing workload and the remaining $18.19 \%$ is affected by other factors.

Husband's fee from non-fishing activity has positive and significant influence towards wife's non-fishing workload where $t_{\text {ratio }}=17.63$ with probability $0.001<0.05(\alpha 5 \%)$ in twoway testing. 0.76 elasticity means every $1 \%$ increase in wife's income from non-fishing activity will increase fishermen's household income as much as $0.76 \%$ with the assumption that other factors are constant.

Equation for Household Food Consumption. Small-scale fishermen's food consumption that consists of rice, protein (meat, fish and egg), frying oil, vegetables, beverage (coffee and tea), fruits, cigarettes and others is influenced by number of family members and household income. The equation is as follows:

$$
K S p n g=d 0+d 1 J A R T+d 2 P D R T+U 4
$$

The result of multiple regression analysis (Anova) conducted simultaneously using SAS version 9.1 is described in Table 8.

Table 8 - Anova of Factors Affecting Food Consumption of Small-Scale Fishermen's Household

\begin{tabular}{llllll}
\hline Variance & $\mathrm{db}$ & Total Square & Median & F-ratio & $\operatorname{Pr}>\mathrm{F}$ \\
\hline Regression & 2 & $5.09 \mathrm{E}+13$ & $2.55 \mathrm{E}+13$ & 50.59 & $<.0001$ \\
Residual & 94 & $4.73 \mathrm{E}+13$ & $5.03 \mathrm{E}+11$ & & \\
Total & 96 & $9.82 \mathrm{E}+13$ & & & \\
\hline
\end{tabular}

Table 8 shows $F_{\text {ratio }}=50.59$ with probability $0.0001<0.01(\alpha=1 \%)$ rejects the null hypothesis. It means the independent variables (number of family members and household income) simultaneously affect household food consumption. T-test is used to find out the influence of independent variables towards dependent variable; the analysis is presented in Table 9.

Table 9 - Estimation of Small-Scale Fisherman's Household Food Consumption

\begin{tabular}{|c|c|c|c|c|c|}
\hline Variabel & Coefficient & Standard Error & t- ratio & $\operatorname{Pr}>|t|$ & Elastic Coefficient \\
\hline Intercept & -1250309 & 399041.8 & -3.13 & 0.0023 & \\
\hline JART & 258410.6 & 37557.84 & 6.88 & $<.0001$ & 0.416 \\
\hline PDRT & 0.636647 & 0.085862 & 7.41 & $<.0001$ & 1.094 \\
\hline
\end{tabular}

Determinant coefficient $\left(R^{2}\right)$ equals to 0.5081 shows that number of family members and household income have $50.81 \%$ influence towards household food consumption whereas the remaining $49.19 \%$ is affected by other factors.

Number of family member has positive and significant influence towards household food consumption where $t_{\text {ratio }}=6.88$ with probability $0.001<0.05(\alpha 5 \%)$ in two-way testing. 
0.41 elasticity means every $1 \%$ increase in number of family member will household food consumption as much as $0.41 \%$ with the assumption that other factors are constant.

Equation for Household Non-Food Consumption. Non-food consumption of small-scale fishermen's household that involves clothing, education, health, electricity, communication, transportation, rent, social activity and other spending is influenced by number of family members, food consumption and household income. The equation is as follows:

$$
K S n p n g=e 0+e 1 J A R T+e 2 K S p n g+e 3 P D R T+U 5
$$

The result of multiple regression analysis (Anova) conducted simultaneously using SAS version 9.1 is described in Table 10.

Table 10 - Anova of Factors Affecting Small-Scale Fishermen's Household Non-Food Consumption

\begin{tabular}{llllll}
\hline Variance & $\mathrm{db}$ & Total Square & Median & F-ratio & $\operatorname{Pr}>\mathrm{F}$ \\
\hline Regression & 3 & $2.34 \mathrm{E}+13$ & $7.78 \mathrm{E}+12$ & 40.48 & $<.0001$ \\
Residual & 93 & $1.79 \mathrm{E}+13$ & $1.92 \mathrm{E}+11$ & & \\
Total & 96 & $4.12 \mathrm{E}+13$ & & & \\
\hline
\end{tabular}

Table 10 shows $F_{\text {ratio }}=40.48$ with probability $0.0001<0.01(\alpha=1 \%)$ rejects the null hypothesis. It means the independent variables (number of family members, food consumption and household income) simultaneously affect household non-food consumption. T-test is used to find out the influence of independent variables towards dependent variable; the analysis is presented in Table 11.

Table 11 - Estimation of Small-Scale Fisherman's Household Non-Food Consumption

\begin{tabular}{llllll}
\hline Variabel & Coefficient & Standard Error & t- ratio & $\operatorname{Pr}>|t|$ & Elastic Coefficient \\
\hline Intercept & -238325 & 488657.6 & -0.49 & 0.6269 & \\
JART & 60790.38 & 90218.65 & 0.67 & 0.5021 & 0.154 \\
KSpng & -1.01821 & 0.337369 & -3.02 & 0.0033 & -1.598 \\
PDRT & 0.963239 & 0.221247 & 4.35 & $<.0001$ & 2.596 \\
\hline
\end{tabular}

Determinant coefficient $\left(R^{2}\right)$ equals to 0.5523

Determinant coefficient $\left(R^{2}\right)$ equals to 0.55231 shows that number of family members food consumption and household income have $55.23 \%$ influence towards household nonfood consmuption whereas the remaining $44.77 \%$ is affected by other factors.

Household income has positive and significant influence towards household non-food consumption where $t_{\text {ratio }}=4.35$ with probability $0.001<0.05$ (a 5\%) in two-way testing. 2.59 elasticity means every $1 \%$ increase in household income will household non-food consumption as much as $2.59 \%$ with the assumption that other factors are constant.

Income of family members affects how much a household spends on goods and service. Such economic behavior is household response as both producers and consumers towards change in market force. Household economic behavior aims at maximixing utility as the assumption of the economic principles.

Individual and household economic behavior has been analyzed systematically by economic experts. The experts analyze household as unit of analysis considering it as the smallest unit of producer as well as consumer; household economic behavior is affected by family member's ability, opportunity and expectation (quoted from various sources).

Chayanov is the pioneer in analyzing farmer's household behavior in 1966; Russian farmer's household became the subjects of the study. Cahayanov developed his theory using the following assumptions, namely: (a) in the farmer's household, there is a correlation between decision-making in production and consumption; (b) each household will work until subjective evaluation from marginal utility works, similar to marginal utility from the output being resulted; (c) there is not any job market which means there is not any income from outside the household; (d) all farmer's households are able to access cultivation area in flexible manner to use in agriculture production processs; (e) there is a public concensus about standard of minimum income an individual should make; dan (f) output from the 
household becomes family consumption or is sold to the market and is valued based on market price.

According to Becker (1965), theory of household economic is production and consumption in a household that cannot be separated from the use of employees that come from the household itself. The theory consider household as the one making decision in both production and consumption as well as the relationship with time allotment and household income. Interaction between consumption and production in farmer's household causes decision-making activity which becomes the unit of various productions. There is some sort of competition in a household about how to spend household income for either production or consumption.

There is a strong interaction between fishing production and dynamic of fish supply and policy related to fishing activities and how to make use of the production (Tai and Heaps, 1996). Mumammad (2002) states that there are production behavior is indicated by three functional variables in integrating bio-economic and relationship between boat owners and employees on fishing vessel; they are fishing boats, fishing ground and productivity in each fishing trip. Productivity is influenced by some productioors namely fishing gears and general condition of the fishing ground.

Social-economic factor frequently found in fisherman's community that affects production and income is non-formal credit institution owned by fish monger. As the effect, fishermen should sell his catch to the fish monger and the fish monger decides the price. It affects the price of the fish the fishermen catch. In conclusion, there is a tendency to establish monopsony/oligopsony; it refers to a type of market with only one or very few buyers (Pindyck and Rubinfeld, 1995).

Economic phenomenon shows there are endogenous and exogenous variables that separate agriculture economic model and fisherman's economic model namely (1) possession of asset, (2) different fishing grounds, (3) system used to share fee from production, and (4) government policy. In line with the previous statement, fishermen's ability to maximixe production is affected by particular factors such as (1) working capital or investment (fishing boats and fishing equipment/ gear), (2) potential of the fishing grounds, (3) days for carrying out fishing activity, (4) access to sell the production with reasonable price, and (5) operational/ production fee (Smith, 1987).

\section{CONCLUSION AND SUGGESTIONS}

Some conclusions based on the findings of the study entitled Household Economic Model for Small-Scale Fishermen through Rural Minapadi (Rice-Fish System) Development Program in Donggala, Central Sulawesi are as follow:

Household economic model and behavior for small-scale fishermen developed in the study is econometric model with production, workload, income and household spending as the variables. The model has been proven as a valid model based on related theories and has accurate level of prediction.

The programs of which purpose is to develop and maintain fishermen's skils in terms of production, workload, income and spending for small-scale fishermen in Donggala are: subsidy for increasing size of the fishermen's rowing boats so that they can fish in productive fishing ground and increase their production; $25 \%$ discounts of gasoline price that has positive impact towards production.

Alternative policy of which goal is an increase in production for small-scale fishermen is $25 \%$ increase in fishing activity, workload and gasoline consumption.

Developing fishing industry more particularly one for small-scale fishermen should be supported by:

Government policy as the instrument to increase production for small-scale fishermen. Government should introduce more effective and productive fishing equipment, subsidy for reducing gasoline price and increasing size of rowing boat into one with at least a 13-PK engine. 
Government policy to increase Fish Aggregating Device (FAD) to save operating fee because FAD attracts more fish when it is used on the fishing ground.

\section{REFERENCES}

1. Aryani, F. 1994. Analisis Curahan Kerja dan Kontribusi Penerimaan Keluarga Nelayan dalam Kegiatan Ekonomi di Desa Pantai. Unpublished Thesis. Graduate Program, Agriculture Institute of Bogor.

2. Bagi, F.S. and I.J. Singh, 1974. A Microeconomic Model of Farm Dicision in an LDC, A Simultanous Equation Approach. Dept. Ag. Ec. And Rural Sociology. The Ohio State University. Colombus-Ohio.

3. Beckers, G. 1965. A Theory of the Alocation of Time. Jour of Economics. Vol. LXXV No. 299, September 1965. Colombia.

4. Muhammad, S. 2002. Kajian Ekonomi Rumahtangga Nelayan: Analisis Simulasi Kebijakan Pengelolaan Sumberdaya Perikanan secara Berkelanjutan. Unpublished Dissertation. Graduate Program, Agriculture Institute of Bogor.

5. Nazir M. 2003. Metodologi Penelitian. Cetakan Kelima. Ghalia Indonesia Jakarat.

6. Parel, 1973. Sampling design and procedures. The Agriculture Devolement Council, New York.

7. Pindyck, R.S and D. Ribinfeld. 1995. Microeconomics. Third Edition Prentice Hall, Englewood Cliffs, New Jersey 07632.

8. Reniati. 1998. Faktor-Faktor yang mempengaruihi dan Keterkaitan Keputusan Kerja Produksi dan Pengeluaran Rumah Tangga nelayan. Unpublished Thesis. Graduate Program, Agriculture Institute of Bogor.

9. Smith, I.R. 1987. Peningkatan Pendapatan Perikanan pada Sumberdaya yang Lebih Tangkap. Ekonomi Perikanan. Yayasan Obor Indonesia dan Gramedia, Jakarta.

10. Sutoyo. 2005. Kajian Ekonomi Rumah tangga nelayan Kecil pada Program Pemberdayaan Pengelolaan Sumberdaya Berbasis Kominitas (PSBK) (Kasus di Muncar Banyuwangi). Unpublished Thesis. Graduate Program, Brawijaya University.

11. Tai, S.Y and T. Heaps, 1996. Effort Dynamic and Alternatives Management Policies for the Small Pelagic Fisheries of Nortwest Painsular Malaysia. Mar. res Economic, Vol II,p. 85-102.

12. Turban Efraim and Jaye Aronso. 1998. Decision Support System and Intellegent System, Fifth Edition. Prentice-Hall Inc. 